\title{
REPRODUCTIVE PERFORMANCE OF YOUNG FEMALE MICE FOLLOWING VAGINAL OPENING
}

\author{
T. G. KENNEDY \\ Department of Veterinary Physiology, University of Sydney, \\ Sydney, N.S.W. 2006, Australia
}

(Received 4th Fune 1973)

Mirskaia \& Crew (1930) have reported that the first vaginal oestrus in young female mice was frequently not associated with mating. In addition, pregnancy followed first mating in only $24 \%$ of cases whereas in the same mice at 3 to 6 months of age, 80 to $90 \%$ of females became pregnant following mating. Since it seemed not unlikely that genetic and/or environmental factors may have contributed to this poor reproductive performance, it was decided to reexamine the fertility of young mice.

Mice of the Quackenbush (QS) strain were used in this study. They were housed under light- and temperature-controlled conditions and given free access to a commercial pelleted mouse food and tap water. The 'young' female mice were 21 days old at the start of the experiment while the 'mature' females were virgin mice approximately 10 weeks old. To determine their reproductive performance, two female mice, one young and one mature, were placed in each of fifty cages containing a mature male QS mouse of unknown fertility. The young mice were examined each morning for vaginal opening; when it was first noted, the age and body weight of the mouse were recorded. A vaginal smear was taken each morning from all unmated female mice, commencing for young mice on the day of vaginal opening. Day 1 of pregnancy was indicated by the presence of a copulation plug or spermatozoa in the vaginal smear. Body weight on Day 1 of pregnancy was recorded. The mice were checked in this fashion for mating for 28 days. During this period, the males were reassigned at random to cages on every 7 th day. Mice which mated were removed from the mating cages before reallocation of the males in order to avoid the possibility of the 'Bruce-effect' operating (Bruce, 1960), and killed on Day 18 of pregnancy. The number of CL of pregnancy was used as an estimate of ovulation rate while an estimate of litter size was obtained from the counts of the number of normally developing fetuses (referred to as viable fetuses).

During the experiment, $6 / 50$ young and $1 / 50$ mature mice died from unknown causes; age had no significant effect on these proportions $\left(\chi_{[1]}^{2}=2 \cdot 46, P>0 \cdot 1\right)$. Mean $( \pm$ S.E.) age and body weight at vaginal opening for young mice which survived were $23 \cdot 5 \pm 0 \cdot 2$ days and $12 \cdot 4 \pm 0.2 \mathrm{~g}$, respectively. For mice which survived, the proportions of mice mating, of mice pregnant at Day 18, of mated mice pregnant at Day 18 and of mice mating at first vaginal oestrus for both age groups are presented in Table 1 . Age had a significant effect $(P<0.05)$ 
only on the proportion of mice which mated during the 28-day observation period.

Mature mice were heavier at mating $(P<0.001)$ than young mice and, on average, mated sooner $(P<0.001)$ after exposure to the males than did young mice (Table 1). For young mice, the interval from exposure to males and mating was calculated as the number of days from vaginal opening to the occurrence of mating. As determined at Day 18 for those mice pregnant, both the numbers of CL of pregnancy and viable fetuses in young mice were less $(P<0.05)$ than the corresponding numbers in mature mice (Table 1). However, on analysis of covariance (Snedecor, 1956) with body weight as the covariate, the adjusted mean numbers of CL of pregnancy for young and mature mice were 11.2 and $11 \cdot 3$, respectively, there being no significant age effect on these adjusted

Table 1. Effects of age on the reproductive performance of young mice during a 28-day observation period

\begin{tabular}{|c|c|c|}
\hline \multirow{2}{*}{ Parameter } & \multicolumn{2}{|c|}{ Group } \\
\hline & roung mice $\dagger$ & Mature mice $\ddagger$ \\
\hline $\begin{array}{l}\text { Proportion of mice mating } \\
\text { Proportion of mice pregnant at Day } 18 \\
\text { Proportion of mated mice pregnant at Day } 18 \\
\text { Proportion of mice mating at first vaginal oestrus } \\
\text { Mean }( \pm \text { S.E.) body weight }(\mathrm{g}) \text { at mating } \\
\text { Mean ( } \pm \text { S.E.) interval (days) between exposure } \\
\text { to males and mating } ₫ \\
\text { Mean }( \pm \text { S.E.) no. of CL of pregnancy } T \\
\text { Mean ( } \pm \text { S.E.) no. of viable fetuses } \uparrow\end{array}$ & $\begin{array}{c}30 / 44(68 \%) \\
19 / 44(43 \%) \\
19 / 30(63 \%) \\
22 / 30(73 \%) \\
22 \cdot 7 \pm 0 \cdot 4 \\
14 \cdot 3 \pm 0 \cdot 9 \\
10 \cdot 7 \pm 0 \cdot 3 \\
9 \cdot 3 \pm 0.5\end{array}$ & $\begin{array}{l}43 / 49(88 \%)^{*} \\
30 / 49(61 \%) \\
30 / 43(70 \%) \\
30 / 43(70 \%) \\
27.5 \pm 0 \cdot 4^{* * *} \\
7 \cdot 0 \pm 1 \cdot 0^{* * *} \\
11 \cdot 9 \pm 0.3^{*} \\
10 \cdot 7 \pm 0.4^{*}\end{array}$ \\
\hline
\end{tabular}

\footnotetext{
* $P<0.05 ; * * * P<0.001$.

$\dagger 21$ days old at start of observations.

$\$ 10$ weeks old at start of observations.

$\$$ For young mice, calculated from day of vaginal opening.

I) Determined at autopsy at Day 18 of pregnancy.
}

means. Similarly, for numbers of viable fetuses, the means after adjustment by analysis of covariance with body weight as the covariate were 10.4 and 10.2 for young and mature mice, respectively. The adjusted means were not significantly different.

For young mice which mated, the body weight at mating of those pregnant at Day 18 was significantly $(P<0.05)$ greater than that of those not pregnant (Table 2). Young mice which mated but were not pregnant at Day 18 tended $(0.05<P<0 \cdot 1)$ to be younger at mating than those which were pregnant. By contrast, there was no significant difference for mature mice in body weight at mating between females which mated and were pregnant at Day 18 and those which mated and were not pregnant.

The results of this investigation confirm the report of Mirskaia \& Crew (1930) that first vaginal oestrus was frequently not associated with mating $(20 \%$ of instances in their data, $27 \%$ in the present data). However, in the present study, the same proportion of mature mice failed to mate at their first vaginal oestrus after exposure to males, indicating that the absence of mating was independent of age. It is not known why some mice did not mate during the 
observation period; unmated mice showed an average of 2.8 vaginal oestrous periods while caged with males. It seems unlikely that the absence of mating can be attributed entirely to faults in male mating behaviour since, in some cases at least, males mated with one female in the cage but not with another although both, on the basis of vaginal smears, were in oestrus. Presumably, the endocrine conditions required for vaginal oestrus are not as stringent as those for oestrous behaviour.

As in the report of Kennedy \& Kennedy (1972) for Sydney White mice, the age effects on the fertility of pregnant mice could be explained in terms of differences between age groups in body weight at mating. Thus, age effects on apparent ovulation rate and litter size were removed by analysis of covariance, using body weight as the covariate.

Table 2. Body weight at mating of young and mature mice found to be pregnant or not pregnant at Day 18

\begin{tabular}{|c|c|c|}
\hline \multirow[b]{2}{*}{ Group } & \multicolumn{2}{|c|}{ Mean $( \pm S . E$.$) body weight (g)$ at mating } \\
\hline & $\begin{array}{c}\text { Mice pregnant } \\
\text { at } \\
\text { Day } 18\end{array}$ & $\begin{array}{c}\text { Mice not } \\
\text { pregnant at } \\
\text { Day } 18\end{array}$ \\
\hline $\begin{array}{l}\text { Young mice* } \\
\text { Mature mice } \dagger\end{array}$ & $\begin{array}{l}23.4 \pm 0.5(19) \\
27.7 \pm 0.5(30)\end{array}$ & $\begin{array}{l}21.5 \pm 0.7(11) \\
27.0 \pm 0.6(13)\end{array}$ \\
\hline
\end{tabular}

The number of mice is given in parentheses.

* 21 days old at start of observations.

$\uparrow 10$ weeks old at start of observations.

Mated young mice which were not pregnant at Day 18 were lighter and tended to be younger at mating than young mice which were pregnant at Day 18. This observation suggests that some young mice mated before they were sufficiently mature to support a pregnancy. It should be noted, however, that age and body weight are confounded in these data, probably to a greater extent than usual because both groups of mice had been raised in litters adjusted at birth to a common size.

The interest and advice of Professor C. W. Emmens is gratefully acknowledged. This work was carried out while the author was the recipient of an Australian Research Grants Committee Post-doctoral Fellowship.

\section{REFERENCES}

BRUCE, H. M. (1960) A block to pregnancy in the mouse caused by proximity of strange males. $\mathcal{J}$. Reprod. Fert. 1, 96.

KenNedy, T. G. \& KenNedy, J. P. (1972) Effects of age and parity on reproduction in young female mice. 7. Reprod. Fert. 28, 77.

Mirskaia, L. \& Crew, F. A. E. (1930) Maturity in the female mouse. Proc. R. Soc. Edinb. 50, 179.

Snedecor, G. W. (1956) Statistical methods, 5th edn. State College Press, Iowa. 